\title{
LANGUAGE ACQUISITION OF DOWN SYNDROME CHILDREN IN THE DOWN SYNDROME VILLAGE PONOROGO: A PSYCHOLINGUISTICS OVERVIEW
}

\author{
Sumarlam $^{1}$, Dwi Purnanto ${ }^{2}$, Sri Pamungkas ${ }^{3}$, Khoirul Hasyim ${ }^{4}$, Angga Cahyaning Utami ${ }^{5}$
}

\begin{abstract}
This study focuses on language acquisition of down syndrome children in the down syndrome village Ponorogo, East Java, Indonesia. The down syndrome villages are Krebet subdistrict of Jambon, Sidoharjo sub-district of Jambon, Karangpatihan sub-district of Sidoharjo, Pandak sub-district of Balong, and Dayakan sub-district Badegan. The purpose of this study are (1) to explain the first language acquisition; (2) to explain the second language acquisition; and (3) to explain the factors that affect language acquisition of down syndrome children in Ponorogo, East Java, Indonesia.

The method of this study is case study in which it seeks the unique phenomena by examining the data description qualitatively. The source of the data are the Down syndrome children and document of information related to them. The data are the Down syndrome children's utterances. The data collection method of this study are observation and interview by applying close and open interview. The triangulation technique of this study are method and source triangulation. The data are analyzed descriptively by using some stages: identifying, classifying, interpreting, and explicating.

The result shows that the down syndrome children aged 7-15 years master the first language (mother tongue) only, it is Javanese in the ngoko level (the Javanese language lowest level). They do not speak Bahasa Indonesia. The Down syndrome children lexical mastery are unique, e.g. pangot to mention knife. They also mention the object based on its sound (onomatopoeic), e.g. eong to mention cat. They eliminate the beginning and the middle consonant, vowel, and also do consonant replacement. Down syndrome children dod not acquire prefix and also the repetition. They do not recognize compound words. They acquire the concepts here and now, the things around him, and now. The do not acquire concept of past and imagination. In addition, children with Down syndrome do echolalia (imitating others), autoecholalia (repeating his own words), verbal auditory agnosia or cogenital word deafness (phonological perception problem). They also impaired speech or stuttering and selective mutism (not speaking to certain situations and places). The Down syndrome children experienced those cases on the onset of their life, although some of them had the problems because of high temperature when they were in 6 months, 1.5 years, and 2 years. Inbreeding, maternal age over 35 years, and malnutrition become a trigger of down syndrome. The factors that affect first and second language acquisition of the Down syndrome children are: (1) rarely to communicate; (2) no bedtime stories before bed; (3) no mother singing before bed; (4) the lack of family attention toward education, especially on language acquisition.
\end{abstract}

Keywords : language acquisition, down syndrome children, psycholinguistic

\section{A. INTRODUCTION}

Children are given the tool by God to be able to speak, that is language acquisition device, as well as children with down syndrome. Children's language development, both normal and down syndrome depends on the learning process 
because the ability to speak is not heredity. Down syndrome children for some people are still considered a disgrace, so often the condition of down syndrome for children is getting worse because of the lack of attention given to them.

This study focuses on language acquisition of down syndrome children which took place in Ponorogo, East Java, Indonesia. The research setting is in Ponorogo, East Java, Indonesia which specifically conducted in five villages, i.e. Krebet sub-district of Jambon, Sidoharjo sub-district of Jambon, Karangpatihan sub-district of Sidoharjo, Pandak sub-district of Balong, and Dayakan sub-district Badegan which are called as down syndrome villages which is predominately suffered from Down syndrome (Radar Ponorogo Wednesday, February 22, 2012).

The approach which used in this study is psycholinguistics. Lado, as cited by Judge (2012) defines psycholinguistics as a combination of two approaches: linguistics and psychology, to study the language knowledge, use of language and related matters impossible assessed from one of the disciplines. Handke (2012) states that psycholinguistics is able to outline the process that people experience in obtaining or using the language. The statement was confirmed by Chaer (2003: 5) the main goal of psycholinguistics is to find theory of language linguistically and psychologically acceptable and it can explain the nature of language as well as its acquisition.

Field (2003) states that there are some important areas in psycholinguistic studies, namely the storage of language, language and the brain, and the use of first language acquisition. Meanwhile, Pateda, cited by Judge (2012) states psycholinguistics studies as: (1) the process of communication and language in the mind; (2) language acquisition; (3) the language patterns of behavior; (4) the issue 
of verbal associations and meanings; (5) the language in the abnormal; (6) speech perception cognition. Thus, it can be said that psycholinguistics tries to explain the nature of language structure and how that structure is obtained, used at regular times, and at times of understanding sentences in the utterance.

This study was conducted to address various issues related to language acquisition of down syndrome children in Down syndrome villages in Ponorogo, East Java, Indonesia. The thing that will be explored is related to (1) first language acquisition both lexical and grammatical skills; (2) acquiring a second language, both lexical and grammatical skills; (3) the factors that affect language acquisition of down syndrome children in the Down syndrome villages in Ponorogo, East Java, Indonesia.

\section{Concept of Language Acquisition}

The process of language acquisition is a process that occurs and takes place in the brain of a child when he obtained his mother tongue (first language). Chaer (2003: 167) distinguishes between acquisition and learning concepts. Learning language (language learning), which deals with the processes that occur at the time when a child is learning a second language, after he obtained his first language. Thus, it can be said that the language acquisition is concerned to the first language, while language learning is concerned to the second language.

Competence and performance process occurs during first language acquisition. Both of these processes have their respective specifications. Competence relates to the mastery of grammar that goes with the unconscious, 
while the performance related to the linguistic abilities that include the ability to understand and ability to produce new words.

There are several hypotheses about language acquisition, namely (1) the conscience hypothesis which is believes that the language has nothing to do with intelligence; (2) the blank slate hypothesis which suggests that color and scratch what would be contained within the child is depend on the people around him in providing writing and color; and (3) cognitive universality hypothesis which claims that children learn the language from the natural surroundings, interact with objects in the surroundings and the people around him. Referring to the three hypotheses above, it is clear that a child in acquiring the language requires a learning stage and facilitation of the people around him.

\section{Stages of Language Acquisition}

Every children have a potential, one of which is the potential of language. Normal children will learn the first language or mother tongue in the early years of his life. This process occurs approximately 5 year. After that, at puberty (approximately 2-14 years old) to adulthood (approximately 18-20 years old), the child will still learn the language (Nababan, 1992: 72).

Acquisition and development of children's first language cannot be separated from the cognitive process, relating to a child's ability to use of acceptable utterances (grammatical). However, in children's language, grammar does not necessarily give a different meaning to the spoken sentences which are uttered. A child can be said to master his first language if there are some important elements that related to mental or cognitive development of the child. 
Developments such as the notion of time, space, modality, and causation are being important parts in the development of a child's cognitive mastery of L1.

The stages of children's language acquisition are as follows: (1) babbling phase (babbling stage), this stage occurs approximately when the children is at 6 months of age. At this stage, the children usually say a large number of utterances that are largely meaningless, and some resembling small piece of a word or words that are merely coincidental; (2) the stage of one word one phrase (holophrastic stage), approximately one year of age. A child starts using a series of sounds repeated for the same meaning. At this age, child understand that the utterance associated with the meaning or start uttering the first words. This stage is called the stage of the same word with a phrase or sentence. This implies that the child's spoken word is a complete concept; (3) the stage of a two words-one phrase, this stage occurs in children aged approximately two years; (4) the stage of "the language resembled telegram", at the age of about two years, the child has begun to master the more complete "sentences". The relationships of syntactic (grammatical

relations) starts to clear, although up to this age that became the topic of conversation is the things concerning himself, which is in place and happening at that time. The language acquisition of normal children was used as the basis for assessing how down syndrome children acquire language.

\section{B. THEORY AND METHOD}

According J.W. Chaplin (1995), Down syndrome is a congenital defect or a physical disability accompanied by mental retardation, thick tongue, and cracked or split, flat face and slanted eyes. Meanwhile, according to Kartini and Gulo (1987), 
Down syndrome is a form of mental retardation caused by an extra chromosome. IQ of down syndrome children is usually below 50 properties. Their physical characteristics are different. Their eyes are oblique upward. Thus, Down syndrome is a condition of mental and physical retardation caused by chromosomal abnormalities. Down syndrome is not contagious because it is genetic. IQ of Down syndrome children can actually be increased by $20 \%$ with intensive learning.

Biologically Down syndrome occurs due to abnormal chromosome composition of 21 of the 23 human chromosomes. In normal people, the 23 chromosomes are in pairs to the number of 46. In patients with down syndrome, chromosome number 21 totaled three (trisomy), bringing the total to 47 chromosomes. The excessive amount shocks to the system resulted in cell metabolism, which eventually causing down syndrome.

Down syndrome is also caused by the lack of certain substances that support the development of nerve cells when the baby is still in the womb, such as a lack of iodine substances. According to data from the UNICEF, Indonesia is estimated lost of 140 million points of Intelligence Quotient (IQ) of each year as a result of iodine deficiency. The same factors have also resulted in 10 to 20 cases of mental retardation annually.

Specific cause is unknown, but the pregnancy by mothers over the age of 35 years is at high risk of having a child with Down syndrome. There are hormonal changes that can lead to "non-disjunction" that occurs on chromosome 21 and translocation of chromosome 15. This can affect the aging process. Mothers aged 35 years and over, during the pregnancy will have a higher risk for having down syndrome children. 
Children and adolescents with Down syndrome has extensive capabilities. Someone who suffers Down syndrome can be very healthy, or even vice versa depending on the drugs consumed. Children with Down syndrome, as well as normal children also have social problems at every stage of life. According C.Njiokiktjen (2005), Down syndrome children have a receptive language disorder because their language comprehension is worse than their expressive language. Receptive and expressive ability are very low (delay or lag), often accompanied by nonverbal disorders (mental retardation experience also). Understanding of language and speech is not at all apparent. In addition, most of them also experience verbal-auditory agnosia or congenital word deafness (mild form of phonologic perception problem). While the semantics of language disorders (sense), pragmatics (use) often begins with echolalia that much, down syndrome children also impaired fluency or stuttering. They sometimes have selective mutism (not speaking to certain situations or places). Most of them have articulation disorders and have a developmental disorders of language and speech.

\section{Research Method}

This research data were in the form of speech / dialogues containing vocabulary and phrases used by down syndrome children in a communication. In addition, the data in this study also contain information on the results of interviews with informants related to the data of language and non-linguistics and interviews with parents' informants.

Marshall and Rossman (1995: 78) state that the source data is a fundamental problem in qualitative research. Therefore, the data source is a very important thing 
to be observed and explored in depth. Sources of data in this study include (1) informants, i.e. down syndrome children in the village of down syndrome in Ponorogo, East Java, Indonesia, in the age of 7-15 years old; (2) documents, i.e. archives or records related to the identity of the informant, the level of parental education, the condition of the elderly, and questionnaire data containing lexical and grammatical abilities of Down syndrome children in Ponorogo, East Java, Indonesia.

The data were collected by using observation, record, and note taking. This study also applied interview technique to gain deeper information from the down syndrome children and their family. The data are validated by using two types of triangulation. That are triangulation of methods and sources.

Data analysis techniques in this study are as proposed by Miles and Huberman (1992). These methods include data collection, data reduction, data display, and drawing conclusions that are in a cycle. Data analysis procedures adopted some stages as follows: (1) identifying the linguistics unit that include word, phrases, and sentences by using the identity (match); (2) classifying the linguistic units based on lexical and grammatical categories; (3) interpreting the linguistic units used in communication by down syndrome children; and (4) explicating the interpretation that has been done on the third procedure.

\section{RESULT AND DISCUSSION}

1. Lexical Identification of The First Language Acquisition of Down Syndrome Children in The Village of Down Syndrome Ponorogo, East Java, Indonesia. 
Lexical identification of down syndrome children in Ponorogo East Java is done by providing 100 data pictures. The research instrument is related to the objects surround them, such as household appliances, animals, school utensils, and others. This strategy aims to gain an idea of how many words acquired by down syndrome children, especially in the village of Down syndrome in Ponorogo, East Java, Indonesia.

Table 1

Lexical acquisition of Down syndrome children in Down syndrome village of Ponorogo, East Java, Indonesia

\begin{tabular}{|c|c|c|c|c|}
\hline Identity & Age & Total of Lexical & Domicile & Note \\
\hline Informant 1 & 9 years & - & Pandak sub-district Balong & \\
\hline Informant 2 & 8 years & - & Pandak sub-district Balong & \\
\hline Informant 3 & 15 years & 100 & Sidoharjo sub-district Jambon & \\
\hline Informant 4 & 12 years & 19 & Sidoharjo sub-district Jambon & \\
\hline Informant 5 & 14 years & - & Sidoharjo sub-district Jambon & \\
\hline Informant 6 & 8 years & 71 & Sidoharjo sub-district Jambon & \\
\hline Informant 7 & 15 years & - & Sidoharjo sub-district Jambon & \\
\hline Informant 8 & 15 years & 16 & Krebet sub-district Jambon & \\
\hline Informant 9 & 16 years & - & Krebet sub-district Jambon & \\
\hline Informant 10 & 14 years & 86 & Krebet sub-district Jambon & \\
\hline Informant 11 & 18 years & - & Krebet sub-district Jambon & \\
\hline Informant 12 & 13 years & - & Krebet sub-district Jambon & \\
\hline Informant 13 & 14 years & - & $\begin{array}{l}\text { Karangpatihan sub-district } \\
\text { Balong }\end{array}$ & \\
\hline Informant 14 & 13 years & 31 & $\begin{array}{l}\text { Karangpatihan sub-district } \\
\text { Balong }\end{array}$ & \\
\hline
\end{tabular}

Based on the above data it can be observed that the majority of children with Down syndrome recognize minimum vocabularies. Of the one hundred data presented, only one informant who was able to identify correctly, the other five are only able to mention a few, and eight others only reacted quietly. 
The down syndrome's word acquisition is unique. Down syndrome children are able to identify, on average, have unique characteristics in mentioning name of an object. The mention of an object with a unique designation, such as montor atus 'aircraft', otos 'truck', papit 'gig', gotos 'rickshaw', yok 'dog', pangot 'knife'. In addition, the down syndrome children also name an object with artificial sounds (onomatopoeic), like calling a cat as eong, replacement and elimination of consonants or vowels, as iying to refer to 'piring' (the plate). Phoneme $/ \mathrm{p} /$ at 'piring' is unmentioned in the beginning of word, while the /r/ is replaced with $/ y /$. Car is pronounced by children with Down syndrome as [obin] while the actual word is mobil (car). Phoneme $/ \mathrm{m} /$ in mobil is eliminated and consonant $/ 1 /$ is replaced by /n/. Data klambi (clothes) was realized as [ambi] with clusters /k1/ eliminated. Topi (cap) is realized as [Øopi]. There is not consonant /t/ at the beginning of the word. The detailed forms of language acquisition in lexical can be seen from the data in the following table.

Tabel 2

First language acquisition (lexical) of the down syndrome children in Ponorogo, East Java, Indonesia

\begin{tabular}{|c|c|c|c|c|}
\hline No & The form of Changing & Data & Realization & Transformation \\
\hline \multirow[t]{4}{*}{1.} & Onomatope & kucing & [eong] & $\begin{array}{l}\text { Pronouncing } \\
\text { according to the } \\
\text { voice of cat }\end{array}$ \\
\hline & & kucing & [pus] & $\begin{array}{l}\text { Pronouncing } \\
\text { according to how } \\
\text { cat is called }\end{array}$ \\
\hline & & kambing & [əmbc?] & $\begin{array}{l}\text { Pronouncing } \\
\text { according to the } \\
\text { voice of goat }\end{array}$ \\
\hline & & anjing & gukguk & $\begin{array}{l}\text { Pronouncing } \\
\text { according to the } \\
\text { voice of dog }\end{array}$ \\
\hline \multirow[t]{3}{*}{2.} & Pronouncing by the unique form & becak & gotos & \\
\hline & & dokar & papit & \\
\hline & & $\begin{array}{l}\text { pesawat } \\
\text { terbang }\end{array}$ & montor atus & \\
\hline
\end{tabular}




\begin{tabular}{|c|c|c|c|c|}
\hline & & truk & otos & \\
\hline & & pisau & pangot & \\
\hline & & anjing & yok & \\
\hline \multirow[t]{6}{*}{3.} & Different concept & tomat & jambu & \\
\hline & & nanas & jarak & \\
\hline & & $t i k$ & menthok & \\
\hline & & garpu & sendok & \\
\hline & & lilin & geni & \\
\hline & & balon & bal 'bola' & \\
\hline \multirow[t]{13}{*}{4.} & Elimination of first consonant & mata & ata [Oto] & $/ \mathrm{m} / \rightarrow \varnothing \sim$ \\
\hline & & tangan & angan & $/ \mathrm{t} / \rightarrow \emptyset \sim$ \\
\hline & & kири-kири & upu & $/ \mathrm{k} / \rightarrow \emptyset \sim$ \\
\hline & & $\begin{array}{l}\text { montor mabur } \\
\text { 'pesawat } \\
\text { terbang' }\end{array}$ & otor abur & $/ \mathrm{m} / \rightarrow \varnothing \sim$ \\
\hline & & mobil & obin & $/ \mathrm{m} / \rightarrow \emptyset \sim$ \\
\hline & & piring & iying & $/ \mathrm{p} / \rightarrow \emptyset \sim$ \\
\hline & & topi & opi & $/ \mathrm{t} / \rightarrow \emptyset \sim$ \\
\hline & & $\begin{array}{l}\text { wedhus } \\
\text { 'kambing' }\end{array}$ & edus & $/ \mathrm{w} / \rightarrow \emptyset \sim$ \\
\hline & & kambil 'kelapa' & ambe & $/ \mathrm{k} / \rightarrow \varnothing \sim$ \\
\hline & & jagung & agung & $\mid \mathrm{j} / \rightarrow \emptyset_{\sim}$ \\
\hline & & sega'nasi' & ego & $/ \mathrm{s} / \rightarrow \varnothing \sim$ \\
\hline & & sambal & ambe & $/ \mathrm{s} / \rightarrow \varnothing \sim$ \\
\hline & & sandal & andal & $/ \mathrm{s} / \rightarrow \varnothing \sim$ \\
\hline \multirow[t]{6}{*}{5.} & $\begin{array}{l}\text { Replacement of the first } \\
\text { consonant with a diffrent } \\
\text { consonant }\end{array}$ & tempe & pepe & $/ \mathrm{t} / \rightarrow / \mathrm{p} / \sim$ \\
\hline & & sepatu & сераtи & $/ \mathrm{s} / \rightarrow / \mathrm{c} / \sim$ \\
\hline & & kaki 'kaos kaki' & tati & $\begin{array}{l}/ \mathrm{k} / \rightarrow / \mathrm{t} / \sim \\
/ \mathrm{k} / \rightarrow / \mathrm{t} / \mathrm{V} / \mathrm{t} / \mathrm{V}\end{array}$ \\
\hline & & balon & dalon & $/ \mathrm{b} / \rightarrow / \mathrm{d} / \sim$ \\
\hline & & bebek 'itik' & kabek & $/ \mathrm{b} / \rightarrow / \mathrm{k} / \sim$ \\
\hline & & $T V$ & pipi & $\begin{array}{l}/ \mathrm{t} / \rightarrow / \mathrm{p} / \sim \\
\sim / \mathrm{v} / \sim \rightarrow \sim / \mathrm{p} / \sim\end{array}$ \\
\hline 6. & $\begin{array}{l}\text { Elimination of the middle } \\
\text { consonant }\end{array}$ & tempe & pepe & $/ \mathrm{m} / \rightarrow \sim \varnothing_{\sim}$ \\
\hline \multirow[t]{3}{*}{7.} & $\begin{array}{l}\text { The elimination of the initial } \\
\text { syllable including consonant } \\
\text { clusters }\end{array}$ & sepeda & $d a h$ & $/$ sepe/ $\rightarrow \emptyset \sim$ \\
\hline & & klambi 'baju’ & ambi & $/ \mathrm{kl} / \rightarrow \varnothing \sim$ \\
\hline & & patelot 'pensil' & eyot & $/$ pat $/ \rightarrow \varnothing \sim$ \\
\hline \multirow[t]{2}{*}{8.} & $\begin{array}{l}\text { Replacement of } \\
\text { consonant with a different } \\
\text { consonant }\end{array}$ & gajah & gadah & $\sim / \mathrm{j} / \sim \longrightarrow \sim / \mathrm{d} / \sim$ \\
\hline & & tawon & tayon & $\sim / \mathrm{w} / \sim \rightarrow \sim / \mathrm{y} / \sim$ \\
\hline 9. & Replacement of first vocal & iwak 'ikan' & uwak & $/ \mathrm{i} / \rightarrow / \mathrm{u} / \sim$ \\
\hline 10. & Elimination of first vocal & iwak 'ikan' & wak & $/ \mathrm{i} / \rightarrow \emptyset \sim$ \\
\hline
\end{tabular}


The data in table 2 can be categorized easily. It is conveyed by informants who know the object. Due to the data above, it can be said that down syndrome children only understand the objects around them, a description of their self, do not recognize the description of parts of the body. All of informants acquired hand only from 13 data about parts of the body which are presented. It is predicted as a result of the visibility of the down syndrome children. The activity is mostly done by hand rather than using their parts of bodies, because the down syndrome children rarely move. They protect their self from surrounding. They also preoccupied with their own world silently and pensively. Their eyes are blank in the enjoyment of their world.

The down syndrome children, especially in Ponorogo, East Java, are only able to provide a realization of the language related to the things that often seen. They only acquire 5 things from 16 data (pictures of animals) such as: wedhus 'goats', pitik 'chickens', gajah 'elephants', iwak 'fish', and kupu 'butterfly'. This would be an interesting thing to be studied because they are on the age of nearly 14 years old. According to the theory of language acquisition, they should be already be included in the foreign language acquisition phase as they are already on early puberty. However, they are only able to identify some animals that are often seen (almost every day), close to their lives, so that they easily give the description. The interesting one is that gajah 'elephant' apparently include in the dominant category of down syndrome children in Ponorogo. Whereas in their lives there is not an elephant. The possibility that occurs is due to its unique shape, large, and specific so that they easily give a description rather than snakes, frogs, lizards, bees, caterpillars and others. In addition, they often see elephant on TV rather than other 
referents. Moreover, the pronunciation of /gajah/ is easier than others. The phoneme $/ \mathrm{g} /$ is generated by the base of the tongue and soft palate (dorso-velar) so that it makes them say easily. In other hand, although /k/ the beginning of word /kodhok/ 'frog' also includes in dorso-velar, but the referent of kodhok 'frog' is very rarely seen by the down syndrome children.

\section{Grammatical Identification on The First Stage of First Language Acquisition}

Grammatical identification in this study is the ability of the down syndrome children in mentioning object in the form of pictures related to daily activity. It refers to the use of phrases, clauses, and sentences in the story telling which is presented by the down syndrome children. Regarding to this case, most of informants were not able to tell the pictures story well. They tend to express it in one word, and some of them did not response, i.e. with a blank stare. The grammatical identification of first language acquisition of the down syndrome children can be seen in the following data.

Tabel 3

Grammatical identification of first language acquisition of down syndrome children

\begin{tabular}{|l|l|l|l|}
\hline No & \multicolumn{1}{|c|}{ Informant } & \multicolumn{1}{|c|}{ Grammatical Data } & \multicolumn{1}{c|}{ Grammatical Meaning } \\
\hline 1. & Informant 6 & mandi & $\begin{array}{l}\text { It refers to the picture of a small child } \\
\text { who was in the shower. }\end{array}$ \\
\hline 2. & Informan 14 & adus nyam 'mandi' & $\begin{array}{l}\text { It refers to the picture of a child who } \\
\text { will be leaving school and said } \\
\text { goodbye to his parents. }\end{array}$ \\
\hline & & $\begin{array}{l}\text { It refers to the picture of a small child } \\
\text { who was in the shower. }\end{array}$ \\
\hline
\end{tabular}




\begin{tabular}{|l|l|l|l|}
\hline & & Mon ayi 'katimun bertani' & $\begin{array}{l}\text { It refers to the men who were working } \\
\text { in the fields. Mon refers to the name of } \\
\text { informant's father (Katimun) who are } \\
\text { working in the fields. }\end{array}$ \\
\hline 3. & Informan 3 & hmm... & $\begin{array}{l}\text { It refers to the picture of a child waking } \\
\text { up }\end{array}$ \\
\hline & agum...'dingin' & $\begin{array}{l}\text { It refers to the picture of a child who } \\
\text { was in the shower }\end{array}$ \\
\hline & $\begin{array}{l}\text { salingan 'bersalaman' } \\
\text { It refers to the picture of a child shake } \\
\text { hands with her mother before go to } \\
\text { school }\end{array}$ \\
\hline & $\begin{array}{l}\text { belajal setulah 'belajar } \\
\text { sekolah' }\end{array}$ & $\begin{array}{l}\text { It refers to pictures of children who are } \\
\text { studying in school }\end{array}$ \\
\hline & $\begin{array}{r}\text { mraktor, nani 'mentraktor, } \\
\text { tani }\end{array}$ & $\begin{array}{l}\text { It refers to the picture of farmer who } \\
\text { was plowing his field with a tractor }\end{array}$ \\
\hline & $\begin{array}{l}\text { tanem 'menanam' } \\
\text { ngabuk 'merabuk' }\end{array}$ & $\begin{array}{l}\text { It refers to the picture of two people } \\
\text { who were planting }\end{array}$ \\
\hline & pertilize \\
\hline
\end{tabular}

According to the table above, it can be said that the first grammatical mastery is still far from normal children. From 16 informants who were interviewed, only 3 of them were able to give a description of the picture story. Three of the informants who gave a description of the pictures by using a single and two words. A word that had been described by the down syndrome children containing the phrase have a special meaning. Likewise, the two words that had been described also refers to a phrase. Normal children will acquire one and two word phrases at age 1 to 2 years old. However, the down syndrome children in Ponorogo acquire this stage in early puberty (the informants in this study were aged 7 to 15 years).

\section{Lexical and grammatical identification of the second language acquisition} on Down Syndrome Children in Ponorogo, East Java, Indonesia

Down syndrome children in the villages of down syndrome, Ponorogo, East Java, Indonesia mastered the first language only. Fourteen informants by the age of 
7 to 15 years old who interviewed, nobody performed a second language production. There were some informants who did not give any response toward the stimulus in which given in the form of pictures of households tools. They use Javanese language by uttering phonological system of their own. It is very difficult to be understood. It needs help from their relative family to reveal the meaning. The down syndrome children answered the questions by using ngoko level of Javanese language (the lowest level of Javanese language). This is caused by their relative family who use ngoko level of Javanese language rather than krama (the higher level of Javanese language), and they also prefer to use Javanese language than Bahasa Indonesia.

\section{Factors Influencing the Language Acquisition on the Down Syndrome Children in Ponorogo, East Java, Indonesia}

(1) Incest

Islam prohibited an incestuous marriage. The result of medical research reveals that an incestuous marriage will get many difficulties in avoiding the occurrence of diseases related to bad genes. It also increasing the chances of getting two copies of harmful genes dramatically. Logically, each person bring a copy of the bad gene and no normal gene that can replace it, so it must have happened likelihood the child will have a short life time, because the scope of genes movement is narrower than a normal marriage.

(2) Mother gave birth over the age of 35 years

The maternal age above 35 years old became the factor the occurrence of the down syndrome children. It can be seen from the condition of the first to the 
third child who born normally, but the fourth child had a down syndrome. This is due to the condition of pregnant women over the age of 35 years old. Female reproductive organs decreases by age so that there is a wide range of degenerative diseases such as hypertension and diabetes.

(3) Lack of nutrition while in the womb

Based on the interviews which are conducted, the condition of down syndrome occurs since they were born, and some of them occur after age 7 months, 1.5 years old, and 2 years old. It begun with the high temperature, bulging eyes. The dominance of down syndrome cases that have occurred since the child was born shows that these conditions occur due to chromosomal abnormalities, which cannot be cured medically. Nevertheless, they still can be educated to responsible to theirself, although very slow, including in acquiring language. However, most of the informants had difficulty in speaking. Some informants did not give any response to the questions which are asked. Factors that affect language acquisition in the down syndrome children in Ponorogo are: (1) rarely to communicate, it causes children to be not familiar with the language; (2) the lack of attention from people nearby, to socialize, interact, and care about themselves and their surroundings as well as learn from the environment (in the house of love); (3) never been given a bedtime story. It is based on the results of the research that bedtime story can improve children's ability to speak and strengthen the character of the children; (4) never been given lullabies singing, which actually meaningful for children and also being prayers to the good; (5) never been given talked 'ngudang' to stimulate the down syndrome children speaking when they are still in the womb. 


\section{CONCLUSION}

Lexical identification of language acquisition of down syndrome children in Ponorogo are as follows: (1) the first informant acquired nothing (there were not any identifiable words), (2) the second informant acquired nothing (there were not any words that can be identified), (3) the third informant acquired 100 words (able to mention and identify all the pictures), (4) the fourth informant acquired 19 words; (5) the fifth informant acquired nothing (there were not any identifiable words); (6) the sixth informant acquired 71 words, (7) the seventh informant informant acquired nothing (there were not any identifiable words); (8) the eighth informant acquired 18 words; (9) the ninth informant informant acquired nothing (there were not any identifiable words); (10) the tenth informant acquired 91 words; (11) the eleventh informant informant acquired nothing (there were not any identifiable words); (12) the twelfth informant informant acquired nothing (there were not any identifiable words), (13) the thirteenth informant informant acquired nothing (there were not any identifiable words); (14) the fourteenth informant acquired 31words. This condition is certainly very alarming because normal children (at the age of 6 years) they have mastered the 2600 words and capable to arrange words into sentences. Based on the realization of lexical identification, the results of research showed that there were some words that described by using a unique word by using the down syndrome children own words. This word is only known by their self. In

addition, the pattern of elimination initial consonant, final consonant, initial 
consonant replacement, initial vowel replacement, mid vowel and another vowel, are similar to the replacement of the first syllable.

Grammatical identification on first language acquisition of the down syndrome children are only in the form of one and two words. Second language acquisition is not identified at all. Down syndrome Children in Ponorogo only knows Javanese 'ngoko' language level. The barriers of pronunciation are the lack of clarity of pronunciation (verbal auditory agnosia or cogenital word deafness) due to the lack of intensity to talk, to read, and listen to a singing before bed (ura-ura). Moreover, they only know a simple sentence. They did not recognize repetition, and did not know the prefix. Some informants gave response by mutism (do not want to speak in certain situations and places) and asymbolic mental retardation (mute autistic), which is apparently not understanding the language and speech.

\section{BIBLIOGRAPHY}

Ahmadi, A. dan Munawar S. 2005. Psikologi Perkembangan. Jakarta: Rineka Cipta.

Asmaroini, Ambiro Puji. 2012. "Efektivitas Bantuan Sosial Bagi Masyarakat Kampung Idiot di Desa Karangpatihan Kecamatan Balong Kabupaten Ponorogo". Skripsi. Malang: Jurusan Hukum dan Ketatanegaraan, Fakultas Ilmu Sosial.

Chaer, Abdul. 2003. Psikolinguistik Kajian Teoretik. Jakarta: Rineka Cipta.

Chaplin, J.P., Kamus Lengkap Psikologi, Alih bahasa: Kartono Kartini, 1999, Jakarta:Raja Grafindo Persada.

Dardjowidjoyo, Soenjono. 2005. Psikolinguistik. Jakarta: Yayasan Obor Indonesia.

Dyer, L. 2009. Meningkatkan Kemampuan Bicara Anak. Jakarta: Bhuana Ilmu Populer.

Field, J. 2004. Psycholinguistics the Key Cocepts. London: Roorledge.

Hakim. 2012. Psikolinguistik dan Kajiannya.?

Handke. 2012. Psycholinguistics-Introduction. The Virtual Linguistic Campus. 
Purwo, Bambang Kaswanti. 2009. "Perkembangan Bahasa Anak dari Lahir Sampai Masa Prasekolah" dalam Bambang Kaswanti Purwo (ed). PELLBA 3. Yogyakarta: Kanisius.

Sari, Gustiana Permata. 2010. "Pemerolehan Kosakata Anak Syndrom Down: Studi Kasus pada Rahma Usia 6 Tahun".

Subroto, D. Edi. 2007. Pengantar Metoda Penelitian Linguistik Struktural. Surakarta: UNS Press.

Subyakto-Nababan.1992. Psikolinguistik Suatu Pengantar. Jakarta: PT Gramedia Pustaka Utama.

Sudaryanto. 1993. Metode dan Aneka Teknik Analisis Bahasa: Pengantar Penelitian Wahana Kebudayaan secara Linguistis . Jakarta: Duta Wacana Unversity Press.

Sutopo, H. B. 2002. Metodologi Penelitian Kualitatif. Surakarta: Sebelas Maret University Press.

Radar Ponorogo. Rabu 22 Februari 2012. "Kampung Down Syndrome”.

Ratna, Nyoman Kutha.2010. Metodologi Penelitian Kajian Budaya dan Ilmu Sosial Humaniora pada Umumnya. Yogyakarta: Pustaka Pelajar.

Zahro, Fatimatuz. 2010. "Budaya Komunikasi Kampung Idiot (Studi Kualitatif di Desa Karangpatih Ponorogo)".

Semiun, Yustinus.Drs. OFM, Kesehatan Mental 2, 2006, Yogyakarta: Kanis... (Anggota IKAPI)

Chaplin, J.P., Kamus Lengkap Psikolog , ...ih bahasa: Kartono Kartini, 1999, Jakarta:Raja Grafindo Persada.

Teori Baru Penyebab Down Syndrome URL:http://health.kompas.com $/ \mathrm{read} / 2010 / 03 / 29 / 11191896 / \mathrm{www}$. kompas.com, diunduh pada tanggal 09 januari 2013, pada pukul 15.25

Model bimbingan dan konseling dengan pendekatan ekologis.Disertasi. Bandung. Pasca sarjana IKIP Bandung.www. Soina.com

http://antoek.blogspot.com/2012/12/laporan-observasi-dan-wawancara-di-slb.html di unduh pada tanggal 10 Januari 2013, pukul 02.30

[1] Teori Baru Penyebab Down Syndrome

URL:http://health.kompas.com/read/2010/03/29/11191896/www.kompas.com, diunduh pada tanggal 09 januari 2013, pada pukul 15.25

[2] Chaplin, J.P., Kamus Lengkap Psikologi, Alih bahasa: Kartono Kartini, (Jakarta, Raja Grafindo Persada,1999)

[3] Model bimbingan dan konseling dengan pendekatan ekologis.Disertasi. Bandung. Pasca sarjana ikip Bandung.www. Soina.com

[4] http://antoek.blogspot.com/2012/12/laporan-observasi-dan-wawancara-di-slb.html di unduh pada tanggal 10 januari 2013, pukul 02.30 